Choremis, C., Fessas, Ph., Kattamis, Chr., Zannos-Mariolea, L., Stamatoyiannopoulos, G., Karaklis, A., and Belios, G. (1963). Lancet. In press.

- Zannos-Mariolea, L., and Kattamis, M. D. C. (1962). Lancet, $1,17$.

Dern, R. J., Weinstein, I. M., Leroy, G. V., Talmage, D. W., and Alving, A. S. (1954). J. Lab. clin. Med., 43, 303.

Doxiadis, S. A., Fessas, Ph., and Valaes, T. (1961). Lancet, 1, 297. Fessas, Ph., Doxiadis, S. A., and Valaes, T. (1962). Brit. med. J., 2, 1359 .

Larizza, P., Brunetti, P., Grignani, F., and Ventura, S. (1958). Haematologica (Basel), 43, 205.

Marks, P. A., and Gross, R. T. (1959). J. clin. Invest., 38, 2253.

— and Hurwitz, R. E. (1959). Nature (Lond.), 183, 1266.
Motulsky, A. G., and Campbell-Kraut, J. M. (1962). In Proceedings of the Cunference on Genetic Polymorphisms and Geographic Variations in Disease, edited by B. S. Blumberg, p. 159. Grune and Stratton, New York.

Panizon, F. (1960), Lancel, $2,1093$.

Ramot, B., Szeinberg, A., Adam, A., Sheba, C., and Gafni, D. (1959). J. clin. Invest., 38, 1659.

Smith, G. D., and Vella, F. (1960). Lancet, 1, 1133.

Szeinberg, A., Sheba, C., Hirshorn, N., and Bodonyi, E. (1957). Blood. 12, 603.

Zannos-Mariolea, L., and Kattamis, Chr. (1961). Ibid., 18, 34.

- and Paidoucis. M. (1962). Brit. J. Haemat., 8, 258.

Zinkham, W. H., Lenhard, R. E., and Childs, B. (1958). Bull. Johns Hopk. Hosp., 102, 169.

\title{
RENAL FUNCTION IN PATIENTS WITH UNILATERAL HYDRONEPHROSIS
}

BY

\author{
MARGARET M. PLATTS, M.D., M.R.C.P., D.Obst.R.C.O.G. J. L. WILLIAMS, M.B., F.R.C.S. \\ From the Departments of Medicine and Urology, the Royal Hospital, Sheffield
}

Few observations have been made on renal function in chronic hydronephrosis in man. Berlyne (1961) demonstrated that patients with chronic bilateral hydronephrosis may have an impaired ability to concentrate and acidify the urine, and there have been reports of isolated cases which showed excessive loss of either sodium or water in the urine (Black and Wagner, 1955; Winberg, 1959). Relief of obstruction of the urinary tract due to stone or prostatic hypertrophy may be followed by polyuria and an increased excretion of sodium (Wilson et al., 1951 ; Roussak and Oleesky, 1954 ; Earley, 1956 ; Bricker et al., 1957 ; Knowlan et al., 1960).

The present investigation was designed to study the function of chronic hydronephrosis in humans in more detail. For this purpose patients with unilateral disease were selected so that the function of the hydronephrosis could be compared with that of the normal kidney. These patients also had no uraemia or electrolyte disturbance, so that dysfunction of the kidney could not be ascribed to extrarenal influences. A preliminary account of this work has already been published (Platts and Williams, 1962).

\section{Clinical Material}

Eight females and four males were investigated. They were selected only in so far as they all had unilateral hydronephrosis and were admitted for operation to relieve the obstruction. The diagnosis was made by excretion urography and retrograde pyelography, which showed dilatation and retention of the dye in the pelvis. Ten of these patients had an obstruction at the pelvi-ureteric junction which was relieved by an Anderson-Hynes plastic repair (Anderson and Hynes, 1949). Aberrant vessels were found in only two patients, and they were not thought to be the cause of the obstruction, which was presumed to be of the so-called " functional " type. One similar patient (Case 10) has not yet been operated upon. One patient (Case 11) had a gross hydronephrosis and hydroureter which were relieved by reimplanting the lower end of the ureter into the bladder.

Nine of these patients presented with pain, three with haematuria, two with symptoms referable to hypertension (Cases 3 and 4), and one with frequency and nausea. All those who have been operated upon have been relieved of symptoms referable to the urinary tract. Five patients were hypertensive at the time of investigation (Table I). The highest blood-urea concentration was $46 \mathrm{mg} . / 100 \mathrm{ml}$. (Table II). In two patients the urine from the hydronephrosis was infected.
An attempt was made to grade the severity of the hydronephrosis by measuring the area of the pelvis and calices as seen on either the excretory urogram or the retrograde pyelogram, and where possible the thickness of the renal parenchyma was measured on the films (Table I). At the time of operation an estimate of the thickness of renal tissue and the volume of the pelvic fluid was made.

\section{Methods}

Clearance studies were made on each kidney after catheterization of each ureter and insertion of a Foley catheter into the bladder under sacral anaesthesia, using $2 \%$ procaine.

Leakage around the ureteric catheter was common at first, but when further holes were made in the catheters this was largely prevented. The catheter was inserted into the hydronephrotic sac, its position being obvious from the copious flow of urine. On the normal side the catheter was located in the upper ureter.

Table I.-Clinical Features of Hydronephrotic Patients

\begin{tabular}{|c|c|c|c|c|c|c|c|c|}
\hline $\begin{array}{l}\text { Case } \\
\text { No. }\end{array}$ & $\begin{array}{l}\text { Sex } \\
\text { and } \\
\text { Age }\end{array}$ & $\begin{array}{l}\text { Pelv. } \\
\text { Area } \\
\text { (sq. } \\
\text { cm.) }\end{array}$ & $\begin{array}{l}\text { Pelv. } \\
\text { Vol. } \\
\text { (ml.) }\end{array}$ & $\begin{array}{c}\text { Tissue } \\
\text { Thick- } \\
\text { ness } \\
\text { (cm.) }\end{array}$ & B.P. & $\begin{array}{c}\text { Urine } \\
\text { Protein }\end{array}$ & $\begin{array}{c}\text { Urine } \\
\text { Infec- } \\
\text { tion }\end{array}$ & $\begin{array}{l}\text { Urine- } \\
\text { reducing } \\
\text { Sub- } \\
\text { stance }\end{array}$ \\
\hline $\begin{array}{r}1 \\
2 \\
3 \\
4 \\
5 \\
6 \\
7 \\
8 \\
9 \\
10 \\
11 \\
12\end{array}$ & $\begin{array}{ll}\mathrm{F} & 36 \\
\mathrm{~F} & 41 \\
\mathrm{M} & 58 \\
\mathrm{~F} & 32 \\
\mathrm{P} & 28 \\
\mathrm{~F} & 39 \\
\mathrm{~F} & 19 \\
\mathrm{~F} & 38 \\
\mathrm{M} & 13 \\
\mathrm{M} & 28 \\
\mathrm{M} & 42 \\
\mathrm{~F} & 32\end{array}$ & $\begin{array}{c}21 \\
22 \\
38 \\
46 \\
50 \\
55 \\
59 \\
84 \\
45 \\
101 \\
\text { v. } \operatorname{large} \\
94\end{array}$ & $\begin{array}{l}\frac{50}{? 7} \\
45 \\
\frac{165}{45} \\
145 \\
150 \\
= \\
500\end{array}$ & $\begin{array}{l}2.0 \\
\frac{1.4}{0 \cdot 5} \\
\overline{0 \cdot 8} \\
\frac{1 \cdot 2}{1 \cdot 2} \\
\frac{-}{0.8}\end{array}$ & $\begin{array}{l}150 / 90 \\
180100 \\
180100 \\
210120 \\
12990 \\
13090 \\
14090 \\
12075 \\
13080 \\
170100 \\
13090 \\
180110\end{array}$ & $\begin{array}{c}\text { Trace } \\
\overline{N i l} \\
+ \\
++ \\
\text { Nil } \\
+\ddot{+} \\
\text { Nil } \\
-+ \\
++ \\
\text { Nil }\end{array}$ & 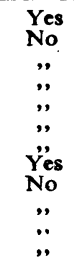 & 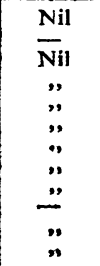 \\
\hline
\end{tabular}

Table II.-Plasma Components in Patients with Unilateral

\begin{tabular}{|c|c|c|c|c|c|c|}
\hline \multirow{2}{*}{$\begin{array}{l}\text { Case } \\
\text { No. }\end{array}$} & \multirow{2}{*}{\multicolumn{2}{|c|}{$\frac{\text { Blood Urea Creatinine }}{\mathrm{mg} .100 \mathrm{ml} .}$}} & $\mathbf{N a}$ & $\mathbf{K}$ & $\mathrm{Cl}$ & \multirow{2}{*}{ mOsm. $/ \mathbf{k g}$} \\
\hline & & & \multicolumn{3}{|c|}{$\left(\mathrm{mEq}^{\prime} \mathrm{l}.\right)$} & \\
\hline $\begin{array}{l}3 \\
5\end{array}$ & $\begin{array}{l}35 \\
33\end{array}$ & $0 . \overline{89}$ & $\begin{array}{l}142 \\
140\end{array}$ & $\begin{array}{l}4.0 \\
4.9\end{array}$ & $\begin{array}{l}101 \\
105\end{array}$ & $=$ \\
\hline $\begin{array}{l}1 \\
2 \\
4 \\
6 \\
7 \\
8\end{array}$ & $\begin{array}{l}46 \\
42 \\
22 \\
12 \\
12\end{array}$ & $\begin{array}{l}1.03 \\
\frac{1}{1 \cdot 16} \\
\frac{\overline{0}}{0.76}\end{array}$ & $\begin{array}{l}149 \\
148 \\
148 \\
142 \\
135\end{array}$ & $\frac{3.9}{-}$ & $\begin{array}{l}108 \\
105 \\
109 \\
106 \\
104\end{array}$ & $\begin{array}{l}292 \\
282 \\
300 \\
282 \\
272\end{array}$ \\
\hline $\begin{array}{r}9 \\
10 \\
11 \\
12\end{array}$ & $\frac{30}{36}$ & $\bar{z}$ & $\begin{array}{l}132 \\
149 \\
137\end{array}$ & $\begin{array}{l}4 \cdot 0 \\
\frac{4 \cdot 9}{3 \cdot 7}\end{array}$ & $\begin{array}{r}94 \\
108 \\
107 \\
100\end{array}$ & $=$ \\
\hline
\end{tabular}


Three hours before the studies were begun each patient drank $500 \mathrm{ml}$. of water and continued to drink approximately $200 \mathrm{ml}$. each half-hour until the end of the observations. About three hours before the clearances nine of the patients received intravenous priming doses of inulin and para-amino-hippurate (P.A.H.) followed by a maintenance infusion of inulin and P.A.H. in normal saline, which was allowed to run at a constant rate until the end of the study. Thus an attempt was made to establish a steady state of water and electrolyte excretion before starting the clearance collections. The other three patients were studied after oral water-loading, but with no infusion ; in these patients the glomerular filtration rate (G.F.R.) was estimated from the endogenous creatinine clearance and P.A.H. was given as small intravenous and intramuscular injections. One patient (Case 5) received $500 \mathrm{mg}$. of acetazolamide intravenously after the first clearance period.

Initially it had been intended to obtain clearance measurements from urine obtained below the site of obstruction and again when the catheter had been passed into the renal pelvis. Preliminary studies showed that this was not feasible because the flow of urine below the obstruction was too small. All the results except those in Case 3 therefore represent the function of the hydronephrotic kidneys shortly after drainage of the pelvis, when the kidney was not subject to a raised intrapelvic pressure. In Case 3 the catheter could not be pushed into the pelvis and all clearances were from below the obstruction.

After insertion of the catheter into the pelvis, urine was allowed to drain until it was thought that the hydronephrotic sac was empty. Two to four consecutive clearance measurements were then carried out, each of 7 to 20 minutes' duration. A specimen of venous blood was obtained at the beginning and end of each urine-collection period.

No serious complications developed after the clearance studies. Occasionally transient renal colic occurred. Urine from the renal pelvis was taken for culture at the subsequent operation and no kidney was infected by the investigation. The urine was infected before the study in Case 1. Case 8 had pain in the loin after operation, and a ureteric catheter was inserted into the hydronephrotic pelvis and left to drain for 24 hours. The clearance studies were done during this period, and the urine was found to be infected at the time the catheter was inserted.

Analytical Methods.-These were as follows. Na, K, and $\mathrm{Ca}$ : flame-photometry. $\mathrm{Cl}$ : potentiometric titration with silver nitrate (Sanderson, 1952) or microdiffusion (Conway, 1950). Ammonia: microdiffusion (Conway, 1950). $p \mathrm{H}$ and titratable acid: Cambridge $\mathrm{pH}$-meter. Bicarbonate: manometric Van Slyke (Peters and Van Slyke. 1932). Bicarbonate was measured only in urine in which the $p \mathrm{H}$ was more than 6.5 , and was assumed to be nil in urines more acid than this. Osmolality: Fiske osmometer. Aminoacids: two-dimensional chromatography with phenol and butanol-acetic acid. Inulin: hydrolysis and colorimetric measurement with resorcinol (Dick and Davies, 1949). P.A.H. : Bratton-Marshall reaction (Smith et al., 1945). Creatinine: Jaffés reaction (Bonsnes and Taussky, 1945).

Some measurements could not be made on every specimen because the volume of urine was too small.

\section{Calculations}

The amount of a substance excreted per litre of glomerular filtrate

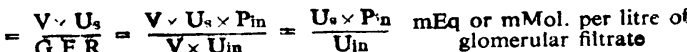

where :

$$
\begin{aligned}
& \mathrm{V}=\text { Urine flow in ml.' } m i n . \\
& \text { Us }=\text { Urine concentration of substance under consideration } \\
& \text { in mEq or mMol. . . } \\
& \text { Uin = Urine inulin concentration in mg. } 100 \mathrm{ml} . \\
& \text { Pin = Plasma inulin concentration in mg. } 100 \mathrm{ml} .
\end{aligned}
$$

Thus a quantitative comparison between the two kidneys could be made without knowledge of the rate of urine-flow from either side. In the patients indicated in Table IV these calculations were made from creatinine or urea concentrations instead of inulin. The urea ratio was used when the sac had not been completely drained. In these patients the inulin concentration was too low because newly formed urine was diluted by that present in the sac before the infusion was begun.

Acid secreted per litre of glomerular filtrate =:

$$
\frac{\left.\mathrm{Pin} \times\left(\mathrm{NH}_{4}\right)+(\text { T.A. } *)-\left(\mathrm{HCO}_{\mathbf{8}}\right)\right)}{\mathbf{U}_{\text {in }}}
$$

The statistical significance of the results was asessed by using the " $t$ " test for means of differences.

\section{Results}

The validity of the comparison of the function of the two kidneys depends on the simultaneously collected specimens of urine being, in fact, formed by the two kidneys at the same time. This does not happen if a reservoir of urine persists in the hydronephrosis. Even when the reservoir in the pelvis has been removed there may be some delay in the passage of newly formed urine from the hydronephrotic pelvis. This relatively short time-lag would not seriously affect the results because the patients were in a steady diuretic state.

The hydronephrotic reservoir was considered to be empty when the volume of urine drained off exceeded the volume measured at operation. When no actual pelvic-volume measurements were available the pelvis was judged to be

\begin{tabular}{|c|c|c|c|c|c|c|}
\hline \multirow{2}{*}{$\begin{array}{l}\text { Case } \\
\text { No. }\end{array}$} & \multirow{2}{*}{$\begin{array}{c}\text { Pelvic } \\
\text { Area } \\
\text { (sq. cm.) }\end{array}$} & \multirow{2}{*}{$\begin{array}{c}\text { Pelvic } \\
\text { Volume } \\
(\mathrm{ml} .)\end{array}$} & \multicolumn{2}{|c|}{ G.F.R. (ml. $\min )}$. & \multicolumn{2}{|c|}{ E.R.P.F. (ml. $\mathrm{min})}$. \\
\hline & & & $\mathbf{H}$ & $\mathbf{N}$ & $\mathbf{H}$ & $\mathbf{N}$ \\
\hline $\begin{array}{c}5 \\
\text { (Creati- } \\
\text { nine) }\end{array}$ & 50 & & \begin{tabular}{|c|}
88 \\
(before ace \\
60 \\
(after acet \\
46 \\
53
\end{tabular} & $\begin{array}{c}85 \\
\text { zolamide) } \\
90 \\
\text { olamide) } \\
40 \\
46\end{array}$ & & \\
\hline $\begin{array}{c}1 \\
\text { (Creati- } \\
\text { nine) }\end{array}$ & 21 & 50 & $\begin{array}{l}9 \cdot 1 \\
4 \cdot 8 \\
3.9 \\
4 \cdot 1\end{array}$ & $\begin{array}{l}55 \\
50 \\
50 \\
57\end{array}$ & $17 \cdot 3$ & 194 \\
\hline $\begin{array}{c}\mathbf{6}^{\text {(Inulin) }} \\
\text { (1) }\end{array}$ & 55 & 165 & $\begin{array}{l}36 \\
35 \\
37\end{array}$ & $\begin{array}{l}70 \\
71 \\
67\end{array}$ & $\begin{array}{l}187 \\
179 \\
217\end{array}$ & $\begin{array}{l}230 \\
246 \\
214\end{array}$ \\
\hline $\begin{array}{c}8 \\
\text { (Creati- } \\
\text { nine) }\end{array}$ & 84 & 145 & $\begin{array}{r}11 \cdot 3 \\
9 \cdot 0 \\
16 \cdot 5 \\
17.9\end{array}$ & $\begin{array}{l}90 \\
79 \\
80 \\
78\end{array}$ & & \\
\hline
\end{tabular}
virtually empty when the urea/inulin concentration ratios were approximately the same in urine from both kidneys and when some variation in composition was seen in suc-

TABLE III.-Glomerular Filtration Rate and Renal Blood Flow in Four Patients in Whom Pelvic Emptying and Urine Collection From Each Ureter Were Complete

$\mathrm{H}=$ Hydronephrosis. $\mathrm{N}=$ Normal kidney

cessive specimens of urine from the hydronephrosis. Incomplete drainage was characterized by an unnatural constancy in the composition of the urine. On these criteria seven patients were judged to have empty hydronephrotic sacs. In Case 3 urine was collected from below the obstruction, but the patient had a small pelvis and a high urine flow ( $3 \mathrm{ml} . / \mathrm{min}$.), and a constant inulin/urea ratio. He was *T.A. $=$ Titratable acid 
therefore considered to have no effective reservoir and is included with the other seven patients. In four patients the drainage was incomplete. These results are therefore less reliable and are presented separately.

In two patients (Cases 3 and 5) renal function was virtually identical in the two kidneys and the G.F.R. in Case 5 was normal on both sides (Tables III, IV, and V). Case 5 received $500 \mathrm{mg}$. of acetazolamide intravenously after the first clearance period. Changes in urine composition were virtually identical on the two sides. These two patients are therefore regarded as having normal renal function in the hydronephrosis, and their results are not included in the statistical analysis of the differences between the hydronephrosis and contralateral normal kidneys in the other patients. These calculations were carried out, first, on the groups of six patients with deranged function and completely drained renal pelvis, and secondly, on the results from these patients together with those from the four patients with incomplete drainage.

\section{Patients with Abnormal Renal Function in Whom the Hydronephrotic Sac was Emptied}

Because of leakage around the catheters G.F.R. and effective renal plasma flow (E.R.P.F.) could be measured in only three patients (Table III). They all showed varying degrees of reduction on the hydronephrotic side. The filtration fraction could be measured without knowledge of the rate of urine flow. In each of the five patients who received P.A.H. the filtration fraction was lower on the hydronephrotic side.

The osmolality of the urine from the hydronephroses differed less from that of plasma $(280-310 \mathrm{mOsm} . / \mathrm{kg}$.) than did that from the control kidney. Thus in all the patients in whom the urine from the control kidney was hypertonic with respect to plasma the urine from the hydronephrosis was less concentrated. Conversely, in two of the three patients in whom the urine from the normal side was hypotonic, the urine from the hydronephrosis had a higher osmolality.

Five of the hydronephrotic kidneys excreted more water per litre of glomerular filtrate than the contralateral normal kidneys. The patient who was excreting a higher proportion of filtered water on the normal side was secreting a hypotonic urine.

TABLE IV.-Water and Hydrogen-ion Excretion (Average Results of All Clearance Periods)

\begin{tabular}{|c|c|c|c|c|c|c|c|c|c|c|c|}
\hline \multirow{2}{*}{ 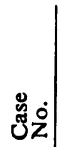 } & \multirow{2}{*}{ 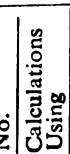 } & \multicolumn{2}{|c|}{$\begin{array}{c}\text { Urine } \\
\text { (mOsm./ } \\
\text { kg.). }\end{array}$} & \multicolumn{2}{|c|}{$\begin{array}{c}\% \\
\text { Filtered } \\
\mathrm{H}_{2} \mathrm{O} \\
\text { Excreted }\end{array}$} & \multicolumn{2}{|c|}{$\begin{array}{c}\text { Filtration } \\
\text { Fraction }\end{array}$} & \multicolumn{2}{|c|}{$p \mathrm{H}$} & \multicolumn{2}{|c|}{$\begin{array}{l}\text { mEqH+ } \\
\text { Secreted pe } \\
\text { L. Glom. } \\
\text { Filt. }\end{array}$} \\
\hline & & $\mathbf{H}$ & $\mathbf{N}$ & $\mathrm{H}$ & $\mathbf{N}$ & $\mathbf{H}$ & $\mathbf{N}$ & $\mathbf{H}$ & $\mathbf{N}$ & $\mathbf{H}$ & $\mathbf{N}$ \\
\hline
\end{tabular}

\begin{tabular}{|c|c|c|c|c|c|c|c|c|c|c|}
\hline \multirow{2}{*}{\multicolumn{2}{|c|}{ Normal R.F.* }} & \multicolumn{9}{|l|}{ Path } \\
\hline & & & & & & & & & & \\
\hline $\begin{array}{l}3 \\
5\end{array}$ & $=17 \overline{735}$ & $\overline{782}$ & $\begin{array}{r}13.2 \\
1.0\end{array}$ & $\begin{array}{r}14.2 \\
1.0\end{array}$ & $\begin{array}{l}0.25 \\
0.15\end{array}$ & $\begin{array}{l}0.24 \\
0.16\end{array}$ & $\begin{array}{l}6 \cdot 40 \\
6 \cdot 38\end{array}$ & $\begin{array}{l}6.40 \\
6 \cdot 03\end{array}$ & $\begin{array}{l}+0.57 \\
+0.29\end{array}$ & $\begin{array}{r}+0.58 \\
+0.65\end{array}$ \\
\hline & & 204 & $9 \cdot 3$ & $4 \cdot 1$ & 0.24 & 0.30 & $7 \cdot 39$ & 6.86 & -0.51 & $+0 \cdot 19$ \\
\hline $\begin{array}{l}2 \\
4\end{array}$ & $\begin{array}{r}90 \\
932\end{array}$ & 61 & $\begin{aligned} 21.4 \\
6.8\end{aligned}$ & $\begin{array}{l}16 \cdot 8 \\
1.8\end{array}$ & $\begin{array}{l}0.25 \\
0.23\end{array}$ & $\begin{array}{l}0.31 \\
0.27\end{array}$ & $\begin{array}{l}6.82 \\
7.87\end{array}$ & $\begin{array}{l}6.69 \\
5 \cdot 31\end{array}$ & $\overline{-0.84}$ & +0.75 \\
\hline 6 & 170 & 109 & 6.9 & $7 \cdot 2$ & 0.19 & $0 \cdot 30$ & 6.41 & 6.02 & $\begin{array}{r}+0.37 \\
+0.59\end{array}$ & $\begin{array}{r}+0.50 \\
+0.65\end{array}$ \\
\hline 8 & $\begin{array}{l}361 \\
156\end{array}$ & $\begin{array}{l}000 \\
333\end{array}$ & 4.0 & $1 \cdot 3$ & & & 7.49 & $6 \cdot 18$ & & \\
\hline & & & & & & & & & & \\
\hline
\end{tabular}

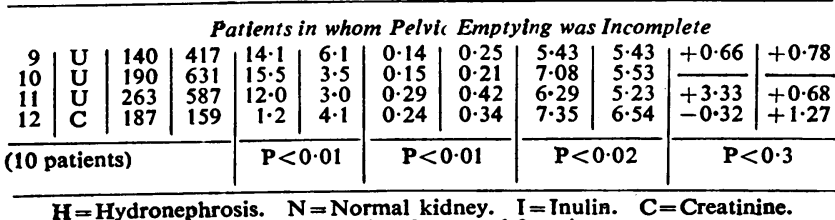

$\mathbf{H}=$ Hydronephrosis. $\mathrm{N}=$ Normal kidney. $I=$ Inulin.
All the patients excreted significantly more sodium, potassium, and chloride per litre of glomerular filtrate from the hydronephrosis than from the normal kidney. There was no consistent difference between the amount of calcium or phosphorus excreted by the kidneys per litre of glomerular filtrate.

In five out of the six patients the $p \mathrm{H}$ of the urine from the hydronephrosis was higher than that from the control side. The total amount of acid secreted into the urine per litre of glomerular filtrate was less on the hydronephrotic side. The difference in $p \mathrm{H}$ and total acid secretion between the normal and hydronephrotic kidneys was not statistically significant.

The Chart shows the persistence of the excretion of a high proportion of the filtered water and sodium by the hydronephrosis in Case 8 throughout 22 hours.

\section{Patients in Whom Pelvic Emptying was Incomplete}

The same general pattern of changes in function was found in the four patients in whom pelvic emptying was TABLE V.-Electrolyte Excretion (Average Results of All Clearance Periods)

\begin{tabular}{|c|c|c|c|c|c|c|c|c|c|c|}
\hline \multirow{3}{*}{$\begin{array}{l}\text { Case } \\
\text { No. }\end{array}$} & \multicolumn{2}{|c|}{$\mathrm{Na}$ Excreted } & \multicolumn{2}{|c|}{$\mathrm{K}$ Excreted } & \multicolumn{2}{|c|}{ Cl Excreted } & \multicolumn{2}{|c|}{ Ca Excreted } & \multicolumn{2}{|c|}{ P Excreted } \\
\hline & \multicolumn{6}{|c|}{$\begin{array}{l}\text { mEq } 1 . \\
\text { Glomular Filtrate }\end{array}$} & \multicolumn{4}{|c|}{$\begin{array}{l}\mathrm{mMol} \mathrm{l}_{\text {iltar Filtrate }} \\
\text { Glomerula }\end{array}$} \\
\hline & $\mathbf{H}$ & $\mathbf{N}$ & $\mathbf{H}$ & $\mathbf{N}$ & $\mathbf{H}$ & $\mathbf{N}$ & $\mathbf{H}$ & $\mathbf{N}$ & H & $\mathbf{N}$ \\
\hline \multicolumn{11}{|c|}{ Patients in whom Pelvic Emptying was Complete } \\
\hline $\begin{array}{c}\text { Normal } \\
3 \\
5\end{array}$ & $\begin{array}{l}\text { R.F.*.* } \\
2 \cdot 28 \\
2 \cdot 29\end{array}$ & $\begin{array}{l}2 \cdot 24 \\
2 \cdot 20\end{array}$ & $\begin{array}{l}0.95 \\
0.36\end{array}$ & $\begin{array}{l}0.91 \\
0.38\end{array}$ & $\begin{array}{l}2 \cdot 28 \\
2 \cdot 16\end{array}$ & $\begin{array}{l}2 \cdot 15 \\
2 \cdot 18\end{array}$ & $\overline{0.049}$ & $0 . \overline{0} 57$ & $\begin{array}{l}1.85 \\
0.07\end{array}$ & $\begin{array}{l}1.86 \\
0.08\end{array}$ \\
\hline $\begin{array}{l}1 \\
2 \\
4 \\
6 \\
7 \\
8\end{array}$ & $\begin{array}{r}4.58 \\
7.36 \\
88.62 \\
3.03 \\
2.97 \\
1.06\end{array}$ & $\begin{array}{l}2.31 \\
4 \cdot 47 \\
1.48 \\
1.36 \\
2 \cdot 17 \\
0.38\end{array}$ & $\begin{array}{l}0.96 \\
1.11 \\
1.97 \\
1.14 \\
0.71 \\
0.57\end{array}$ & $\begin{array}{l}0.72 \\
0.86 \\
1.35 \\
0.96 \\
0.54 \\
0.28\end{array}$ & $\begin{array}{l}0 \cdot 64 \\
6 \cdot 21 \\
4 \cdot 37 \\
4 \cdot 21 \\
2 \cdot 58 \\
0 \cdot 78\end{array}$ & $\begin{array}{l}0.24 \\
4.20 \\
1.78 \\
1.60 \\
2.33 \\
0 \cdot 25\end{array}$ & $\begin{array}{l}0.80 \\
\bar{Z} \\
\overline{\bar{Z}} \\
0.004\end{array}$ & $\begin{array}{c}0.38 \\
= \\
\bar{E} \\
0 \cdot 012\end{array}$ & $\begin{array}{c}14.5 \\
0.19 \\
3.78 \\
0.50 \\
0.09 \\
0.03\end{array}$ & $\begin{array}{c}10.7 \\
0.13 \\
3.71 \\
1.51 \\
0.04 \\
0.37\end{array}$ \\
\hline patients) & \multicolumn{2}{|r|}{05} & \multicolumn{2}{|c|}{$P<0.01$} & \multicolumn{2}{|r|}{.02} & & & \multicolumn{2}{|c|}{$\mathrm{P}<0 \cdot 1$} \\
\hline
\end{tabular}

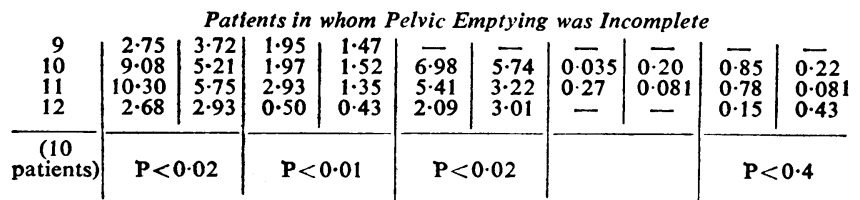

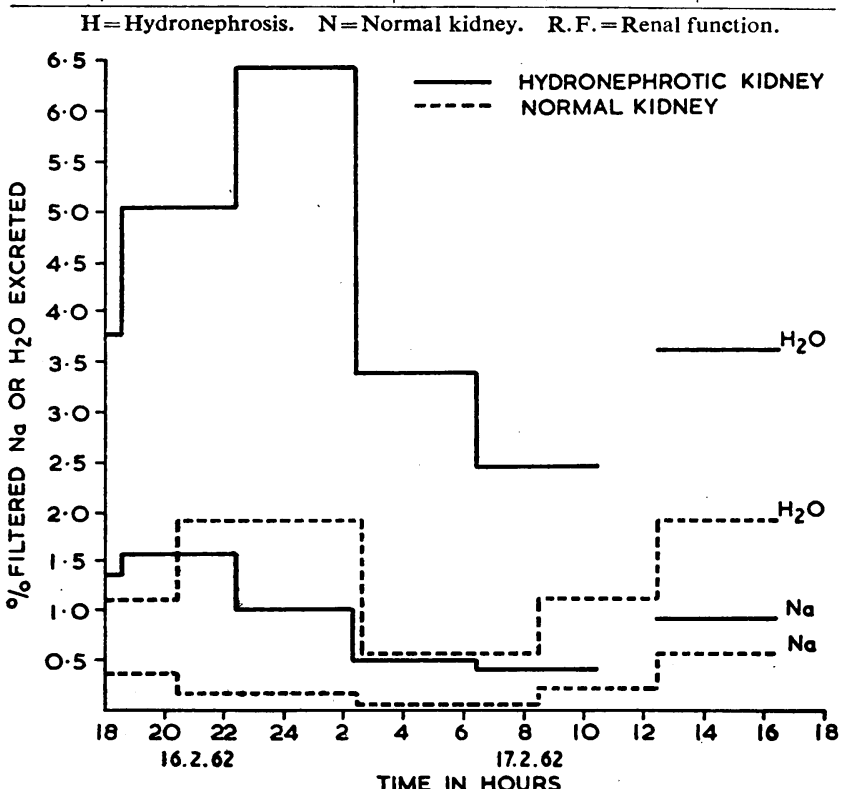

Sodium and water excretion during the first 22 hours after insertion of a catheter into the pelvis of a hydronephrotic kidney. 
incomplete. The main anomaly was in Cases 9 and 12, in which decreased reabsorption of sodium was not demonstrated.

Protein was found in the urine of five patients (Table I).

None of the urines tested contained any reducing substance and no unusual amino-acids were found. The same amino-acids were present in control and hydronephrotic urines, but the concentration in the urine from the hydronephrosis tended to be lower.

\section{Discussion}

We have found no definite correlation between the size of the hydronephrotic sac and the functional impairment of the kidney. This can be attributed to two reasons: (1) the enlargement of an intrarenal pelvis will cause greater destruction of tissue than that of an extrarenal pelvis, and the latter will be usually larger; (2) as pointed out by Edholm and Lindblom (1962), the enlarged calices on the pyelogram give an erroneous impression of the amount of tissue loss as the corresponding increase in size of the kidney is not appreciated.

It has also been difficult to classify the excretory urogram in terms of dye concentration. In the two patients with normal function studies the pyelogram showed good caliceal cupping and dye concentration. In Case 4 no function was seen on the excretory urogram, but this kidney was still secreting urine. All the other patients showed excretion on the urogram.

Examination of the hydronephrotic kidney shows that both cortex and medulla are usually reduced in thickness, many glomeruli are damaged or destroyed, tubules are atrophied or dilated, and the longer loops of Henle and collecting ducts may be destroyed. Derangement of many aspects of renal function may therefore be expected.

Studies in our patients show that the G.F.R., E.R.P.F., and filtration fraction are usually reduced in the hydronephrotic kidney. More sodium, potassium, and chloride are excreted per litre of glomerular filtrate, and the urine is not concentrated and diluted normally. Even in the absence of an acid load the urine from the hydronephrosis tends to be more alkaline than that from the normal kidney, though the difference was not statistically significant. Berlyne (1961) showed that patients with bilateral hydronephrosis could not acidify the urine to the normal extent after ammonium chloride.

Our results reflect the function of the kidney immediately after reduction in pelvic pressure. The reduction in G.F.R. and E.R.P.F. is therefore due to structural changes in the kidney and not to the direct effect of pressure on the renal vasculature. In renal-artery stenosis in man the reduction in G.F.R. and E.R.P.F. is similar in degree to that found in hydronephrosis and the filtration fraction is similarly reduced. In this condition the affected kidney excretes less sodium and water per litre of glomerular filtrate than the normal side (Page et al., 1959; Spencer et al., 1961). Similarly, in animals with otherwise normal kidneys, reduction in G.F.R. with a proportionately smaller reduction in E.R.P.F. does not impair the ability of the kidneys to produce a concentrated urine (Abbrecht and Malvin, 1961). It therefore seems unlikely that the derangements in water and electrolyte excretion seen in hydronephrosis are simply a result of the reduced G.F.R. and E.R.P.F.

In view of the difference in electrolyte excretion in renalartery stenosis and hydronephrosis it is interesting that one of our patients had relief of his hypertension after operation on the pelvi-ureteric junction.
No direct evidence of damage to the proximal tubule was obtained, since no glycosuria or abnormal amino-aciduria was detected. Maximal tubular reabsorptive and secretory tests were not carried out.

Berlyne and Macken (1962) showed that the kidneys of dogs made hydronephrotic by ligation of the ureter a week previously did not show the normal increase in tissue osmolality in the medulla after administration of antidiuretic hormone. It is known that the longer loops of Henle contribute most to the establishment of this gradient, and it is precisely these loops which must be damaged first in hydronephrosis. Moreover, hydronephrotic patients have been shown to have an impaired ability to dilute the urine. This is probably because the fluid entering the distal convoluted tubule from the loop of Henle has had less sodium removed from it than normal. If the osmotic pressure in the medulla is not high urinary concentration also cannot occur.

If less sodium than usual is abstracted from the urine during its passage through the loops of Henle this may be the direct cause of the net impairment of sodium reabsorption by the nephron. In addition there may be impairment of sodium reabsorption in the distal tubule and collectingduct. Since some sodium reabsorption in these situations occurs in exchange for hydrogen and potassium, damage to this mechanism should result in a reduced excretion of acid and potassium. In the present investigation a significant reduction in hydrogen-ion secretion was not demonstrated and the excretion of potassium per litre of glomerular filtrate was increased. It therefore appears that this exchange system is functioning efficiently. The failure of the urine to become highly acid may be due to its low osmolality. If an impairment of net acid secretion can be demonstrated under an acid load, then it would seem that the carbonic anhydrase mechanism for furnishing hydrogen ions for secretion may be damaged, thus allowing preferential secretion of potassium in exchange for sodium in the distal tubule. The only other explanation of the increased potassium excretion would seem to be a failure of reabsorption higher up the nephron.

In these patients with unilateral disease the derangements of function did not produce abnormalities in the composition of the blood, since the normal kidney was able to compensate. In bilateral disease, however, the tendency to water, sodium, and potassium loss may be pronounced and patients with hyponatraemia and hypokalaemia have been seen.

\section{Summary}

Twelve patients with unilateral hydronephrosis were studied by divided renal function tests. In two the function on the hydronephrotic side was normal. In the others the hydronephrotic kidney showed a reduction in glomerular filtration rate, renal plasma flow, and filtration fraction. More sodium, chloride, and potassium were excreted per litre of glomerular filtrate and the urine was not concentrated and diluted normally. An important factor in producing these defects may be a reduction in the ability of the loops of Henle to reabsorb sodium.

We are grateful to Mr. J. C. Anderson for allowing us to study his patients, to Miss B. Ibbotson for technical assistance, and to the nursing staff of the urological department for their help.

RBFERENCES

Abbrecht, P. H., and Malvin, R. L. (1961). Amer. J. Phystol., 201, 754. Anderson, J. C., and Hynes, W. (1949). Brit. J. Urol., 21, 209.

Berlyne, G. M.'(1961). Quart. j. Med., 30. 339

Berlyne, G. M. (1961). Quart. Cin Sci. 22.339.

Black, J., and Wagner, J. (1955). Arch. Dis. Childh., 39, 62. 
Bonsnes, R. W., and Taussky, H. H. (1945). J. biol. Chem., 158, 581.

Bricker, N. S., Shwayri, E. I., Reardan, J. B., Kellog, D., Merrill, J. P., and Holmes, J. H.'(1957). Amer. J. Med., 23, 554.

Conway, E. J. (1950). Microdiffusion Analysis and Volumetric Error. 3rd ed., revised, pp. 87, 184. Crosby Lockwood, London. Dick, A., and Davies, C. E. (1949). J. clin. Path., 2, 67.

Earley, L. E. (1956). New Engl. J. Med., 255, 600.

Edholm, P., and Lindblom, K. (1962). J. Urol., 88, 342

Knowlan, D., Corrado, M., Schreiner, G. E., and Baker, R. (1960). Amer. J. Med. 28, 22

Page, I. H., Dustan, H. P., and Poutasse, E. F. (1959). Ann. intern. Med., 51, 196.
Peters, J. P., and Van Slyke, D. D. (1932). Quantitative Clinical Chemistry, p. 292 Williams and Wilkins, Baltimore.

Platts, M. M., and Williams, J. L. (1962). Proc. roy. Soc. Med. 55, 1037 .

Roussak, N. J., and Oleesky, S. (1954). Quart. J. Med., 23, 147.

Sanderson, P. H. (1952). Biochem. J., 52, 502. Smith, H. W., Finkelstein, N., Aliminosa, L., Crawford, B., and
Graber, M. (1945). J. clin. Invest., 24, 388 .

Spencer, F. C., Stamey, T. A., Bahnson, H. T., and Cohen, A (1961). Ann. Surg., 154, 674 Wilson, B., Reisman, D. D., and Moyer, C. A. (1951). J. Urol.,

Winberg, J. (1959). Acta paediat. (Uppsala), 48, 149.

\section{FAMILIAL STREBLODACTYLY WITH AMINO-ACIDURIA}

\section{J. G. PARISH, M.D., D.Phys.Med.}

Lately Senior Registrar in Physical Medicine, Dryburn Hospital, Durham

\section{B. HORN, Ph.D., F.R.I.C.}

\section{THOMPSON, M.D., M.R.C.P.}

Consultant Physician

From the Departments of Physical Medicine and Clinical Chemistry, the Royal Victoria Infirmary, Newcastle upon Tyne

There has been considerable recent interest in the heritable disorders of connective tissue. We have noted an unusual deformity in the hands of one family residing in the Durham district of N.E. England. The deformity exhibited a mixture of the features of several musculoskeletal syndromes reported previously.

Marfan (1896) described the presence of flexion contractures of the small joints of the hands and feet in a 5-yearold girl as a part of a general musculoskeletal disorder in which the characteristic finding was excessive length and slenderness of the extremities (dolichomorphism). Achard (1902) was able to demonstrate by radiographs that the slenderness of the fingers in his patient was due to diminution in width of the shafts of the bones without affecting the epiphyses, giving a prominent appearance to the corresponding joints, which simulated arthritis. The joints of the fingers were excessively mobile, and he introduced the term "arachnodactyly" (spider fingers) to describe the appearance of the hands. The patient had certain brachymorphic features of a type not seen in Marfan's syndrome (Parish, 1960). The association of brachydactyly with dwarfism, with brachycephaly, and often with dislocation or spherical lenses was reported by Weill (1932) and Marchesani (1939). Bowers (1959) showed that members of the same family could inherit the features of either Marfan's syndrome or the Weill-Marchesani syndrome.

\section{The Family}

In the family which we have studied the abnormalities have principally involved the hands, producing flexion deformities of some joints and excessive laxity of others, The bone structure has also shown variations, including slenderness of certain phalanges to excessive shortening

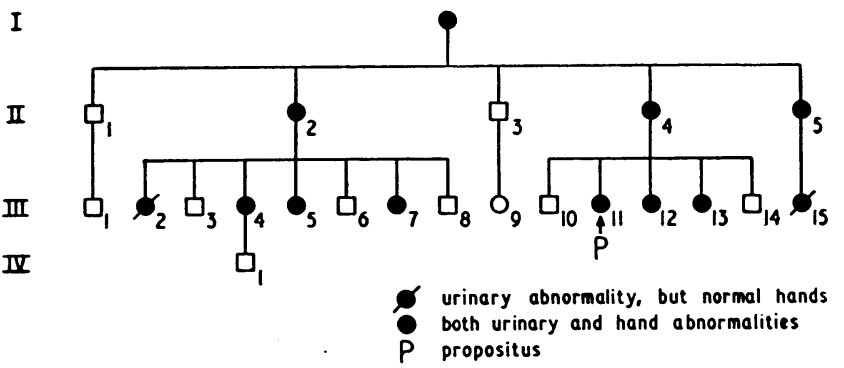

FIg. 1.-Family pedigree through four generations. and broadening of the shafts of the metacarpals. The family pedigree is shown in Fig. 1, the affected members, all females, being indicated by black circles.

\section{Propositus}

The propositus (III 11) was a 20-year-old unmarried woman who was referred to hospital for investigation and treatment of Bell's palsy. During clinical examination it was noted that she had unusual deformities of her fingers (Figs. 2 and 3). Her mother stated that the deformity had been present since birth and affected other female members of the family. In the propositus the following characteristics were noted.

Skeletal Development.-Height $57 \frac{1}{2}$ in. $\left(146 \mathrm{~cm}\right.$.), span $55 \frac{1}{2}$ in. (141 cm.), weight 7 stone $(44.9 \mathrm{~kg}$.), symphysis pubis to vertex 28 in. $(71 \mathrm{~cm}$.), symphysis to ground $27 \mathrm{in.}(68.5 \mathrm{~cm}$.). Her physical appearance was normal, but she had a high arched palate and the infrapatellar distance was above the normal range, being $2 \frac{1}{2}$ in. $\left(6.4 \mathrm{~cm}\right.$.) in the right and $2 \frac{1}{4}$ in. $(5.7 \mathrm{~cm}$.) in the left knee (upper limit 1.8 in. (4.6 cm.), Booth et al. (1957).

Hands.-The prominent features were the flexion deformities of the metacarpophalangeal (mcp.) joints of both thumbs and also of the proximal interphalangeal (pip.) joints of both little fingers (amounting to 45 degrees in the right hand and 30 degrees in the left hand). The swan-neck deformities of the index and middle fingers were associated with hypermobile mcp. joints. Hyperextensibility of the mcp. joints varied from 60 to 65 degrees in the index and middle fingers to 80 degrees in the ring-finger and little finger of the left hand.

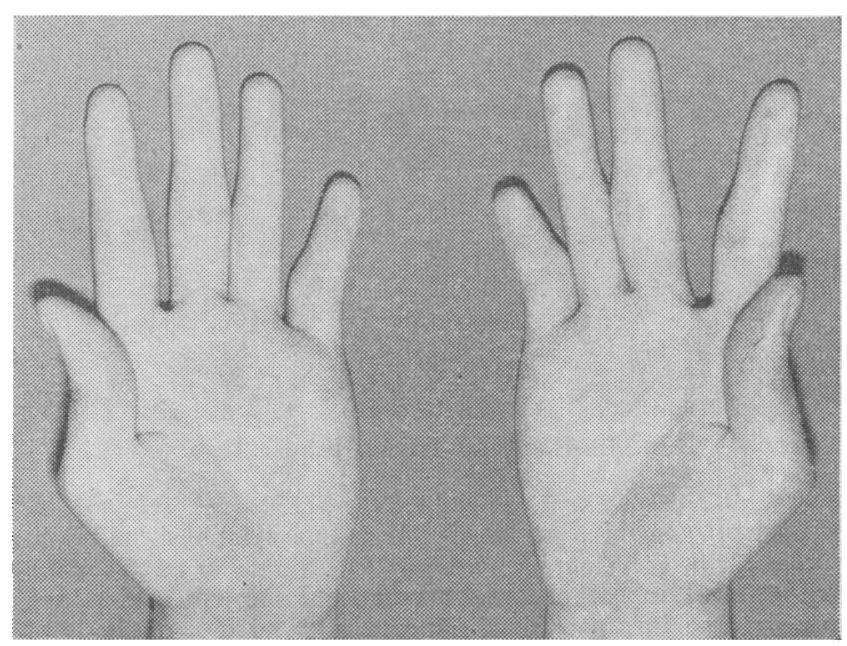

FIG. 2.-Hands of propositus (III 11), palmar view. 